\title{
Fat balance in obese subjects: role of glycogen stores.
}

Citation for published version (APA):

Schrauwen, P., van Marken Lichtenbelt, W. D., \& Westerterp, K. R. (1998). Fat balance in obese subjects: role of glycogen stores. American Journal of Physiology (Consolidated), 274(6 Pt 1), E1027-E1033. https://doi.org/10.1152/AJPENDO.1998.274.6.E1027

Document status and date:

Published: 01/01/1998

DOI:

10.1152/AJPENDO.1998.274.6.E1027

Document Version:

Publisher's PDF, also known as Version of record

\section{Please check the document version of this publication:}

- A submitted manuscript is the version of the article upon submission and before peer-review. There can be important differences between the submitted version and the official published version of record.

People interested in the research are advised to contact the author for the final version of the publication, or visit the DOI to the publisher's website.

- The final author version and the galley proof are versions of the publication after peer review.

- The final published version features the final layout of the paper including the volume, issue and page numbers.

Link to publication

\footnotetext{
General rights rights.

- You may freely distribute the URL identifying the publication in the public portal. please follow below link for the End User Agreement:

www.umlib.nl/taverne-license

Take down policy

If you believe that this document breaches copyright please contact us at:

repository@maastrichtuniversity.nl

providing details and we will investigate your claim.
}

Copyright and moral rights for the publications made accessible in the public portal are retained by the authors and/or other copyright owners and it is a condition of accessing publications that users recognise and abide by the legal requirements associated with these

- Users may download and print one copy of any publication from the public portal for the purpose of private study or research.

- You may not further distribute the material or use it for any profit-making activity or commercial gain

If the publication is distributed under the terms of Article $25 \mathrm{fa}$ of the Dutch Copyright Act, indicated by the "Taverne" license above, 


\title{
F at balance in obese subjects: role of glycogen stores
}

\author{
PATRICK SCHRAUWEN, WOUTER D. VAN MARKEN LICHTENBELT, \\ WIM H. M. SARIS, AND KLAAS R. WESTERTERP \\ Department of Human Biology, Maastricht University, 6200 MD Maastricht, The Netherlands
}

\begin{abstract}
Schrauwen, Patrick, Wouter D. Van Marken Lichtenbelt, Wim H. M. Saris, and Klaas R. Westerterp. Fat balance in obese subjects: role of glycogen stores. Am. J . Physi ol 274 (Endocrinol. Metab. 37): E 1027-E 1033, 1998.-In a previous study, we showed that lean subjects are capable of rapidly adjusting fat oxidation to fat intake on a high-fat (HF) diet when glycogen stores are lowered by exhaustive exercise. However, it has been proposed that obese subjects have impaired fat oxidation. We therefore studied the effect of low glycogen stores on fat oxidation after a switch from a reducedfat (RF) diet to an HF diet in obese subjects. Ten healthy, obese male and female subjects ( $26 \pm 2 \mathrm{yr}$, body mass index $31.8 \pm 1.4$, maximal power output $228 \pm 14 \mathrm{~W}$ ) consumed an RF diet $(30,55$, and $15 \%$ of energy from fat, carbohydrate, and protein, respectively) at home for 3 days on four occasions (days 1-3). On two occasions, subjects came to the laboratory on day 3 at 1500 to perform an exhaustive glycogen-lowering exercise test (Ex), after which they went into a respiration chamber for a 36-h stay. On the other two occasions, subjects directly entered the respiration chamber at 1800 for a 36-h stay. In the respiration chamber, they were fed, in energy balance, either an HF diet $(60,25$, and $15 \%$ of energy from fat, carbohydrate, and protein, respectively) or an RF diet. All diets were consumed as breakfast, lunch, dinner, and two or more snacks per day. Twenty-four-hour respiratory quotient was $0.91 \pm 0.01,0.89 \pm 0.01,0.84 \pm 0.01$, and $0.81 \pm 0.01$ with RF diet, RF + Ex, HF, and HF + Ex treatments, respectively. With the HF treatment, fat oxidation was below fat intake, indicating the slow change of oxidation to intake on an HF diet. After the HF + Ex treatment, however, fat oxidation matched fat intake. In conclusion, obese subjects are capable of rapidly adjusting fat oxidation to fat intake when glycogen stores are lowered by exhaustive exercise.
\end{abstract}

respiration chamber; obesity; fat oxidation

THE HIGH and still increasing prevalence of obesity in affluent societies is known to produce major health hazards. Apart from environmental factors, it is now commonly accepted that obesity is also under the influence of genetic factors. However, the impact of environmental factors in the prevalence of obesity has been illustrated by Ravussin and Tataranni (17). They studied two populations with similar genetic background (Pima I ndians) living in different environments (Mexico and Arizona). The Mexican Pima Indians have a body mass index that is 7-10 units lower than the Arizona Pima Indians, a difference that might be explained by the higher fat intake and lower spontaneous physical activity observed in the Arizona Pima Indians. Other studies $(11,15)$ al so suggest an association between obesity and a high-fat (HF) intake. In humans, it has been shown that fat intake does not promote its own oxidation (21). Furthermore, in preobese or obese subjects, an impaired ability to oxidize fat has been shown $(3,6,24,27)$. Flatt (7) postulated a two-compartment model, in which it is stated that fat oxidation can be increased to match fat intake 1) by maintaining glycogen stores in a lower range or 2) by expansion of the adipose tissue mass. In a previous study (20), we showed that lean subjects were capable of rapidly (within $24 \mathrm{~h}$ ) adjusting fat oxidation to fat intake when glycogen stores were lowered by exhaustive exercise, whereas no complete adjustment of fat oxidation to fat intake occurred without glycogenlowering exercise. However, obesity has been described as a misadaptation to an HF diet (1). This might suggest that preobese or obese subjects are not capable of rapidly adjusting fat oxidation to an HF intake by maintaining glycogen stores in a lower range. Another possibility is, however, that they have fewer fluctuations in the amount of glycogen stored, possibly due to low levels of physical activity. We ther efore investigated whether obese subjects are capable of rapidly increasing fat oxidation on an HF diet when glycogen stores are lowered by exhaustive exercise. We hypothesized that, compared with the lean subject in our previous study, the obese subjects are less capable of rapidly adjusting fat oxidation to fat intake on an $\mathrm{HF}$ diet when glycogen stores are lowered by exhaustive exercise.

\section{MATERIALS AND METHODS}

\section{Subjects}

The characteristics of the 10 volunteers ( 4 men, 6 women) participating in this study are shown in Table 1 . All subjects were healthy, untrained (not active in any sport, no training history), and obese. No gender differences in the measured parameters of interest were observed, and therefore data of males and females are pooled. Subjects' habitual energy intake was $9.5 \pm 0.6 \mathrm{MJ} /$ day, with $30.3 \pm 1.9,51.4 \pm 2.2$, $15.2 \pm 0.8$, and $3.1 \pm 1.1 \%$ of energy from fat, carbohydrate, protein, and alcohol, respectively. The study was approved by the Ethical Committee of the Maastricht University, and subjects gave their written informed consent.

\section{Experimental Design}

Each subject followed four different treatments. Treatments were separated by at least $1 \mathrm{wk}$ and conducted in random order. Each treatment consisted of a 36-h stay in a respiration chamber. To ensure a similar dietary macronutrient composition before all four treatments, food intake was controlled for 3 days before the treatments. Subjects were given a reduced-fat (RF) diet for consumption at home for days 1-3. On two occasions, subjects came to the laboratory on day 3 at 1500 to perform an exhaustive glycogen-lowering exercise test (Ex) and then entered the respiration chamber at 1800 for a 36-h stay. In the respiration chamber, they were 
Table 1. Subject characteristics

\begin{tabular}{|c|c|c|c|c|c|c|c|}
\hline Subjects & $\begin{array}{l}\text { Age, } \\
\mathrm{yr}\end{array}$ & $\begin{array}{c}\mathrm{Ht}, \\
\mathrm{m}\end{array}$ & $\begin{array}{l}\mathrm{Wt} \\
\mathrm{kg}\end{array}$ & $\begin{array}{c}\text { Body Fat, } \\
\%\end{array}$ & $\begin{array}{l}\mathrm{BMI} \\
\mathrm{kg} / \mathrm{m}^{2}\end{array}$ & $\mathrm{~W}_{\max }$, & $\mathrm{W}_{\max } / \mathrm{kg} F F M$ \\
\hline $\begin{array}{l}\text { Total } \\
\text { Males }\end{array}$ & $\begin{array}{l}25.9 \pm 1.8 \\
29.8 \pm 3.6\end{array}$ & $\begin{array}{l}1.76 \pm 0.03 \\
1.87 \pm 0.02 *\end{array}$ & $\begin{array}{c}98.3 \pm 6.0 \\
112.9 \pm 12.1 \dagger\end{array}$ & $\begin{array}{l}38 \pm 3 \\
34 \pm 5\end{array}$ & $\begin{array}{l}31.8 \pm 1.4 \\
32.4 \pm 3.4\end{array}$ & $\begin{array}{l}228 \pm 14 \\
259 \pm 30\end{array}$ & $\begin{array}{l}3.83 \pm 0.20 \\
3.60 \pm 0.49\end{array}$ \\
\hline
\end{tabular}

Values are means \pm SE. BMI, body mass index; $W_{\text {max }}$, maximal power output; $F F M$, fat-free mass. $* P<0.001$ compared with females. $\dagger P<$ 0.05 compared with females.

given either an HF diet (HF + Ex, 60 energy\% fat) or an RF diet $(R F+E x)$. The RF diet contained 30 energy\% fat, as is often recommended in the prevention of obesity (4). On the other two occasions, no glycogen-lowering exercise was performed, but subjects directly entered the respiration chamber at 1800 for a 36-h stay, where they were given either an HF or RF diet. On the morning of day 5, subjects left the respiration chamber at 0800 .

Maximal power output. One week before the experiments, each subject performed an incremental exhaustive exercise test on an electronically braked cycle ergometer (L ode Excalibur, Groningen, The Netherlands) to determine maximal heart rate and maximal power output $\left(W_{\max }\right)$. Exercise was performed until voluntary exhaustion or until the subject could no longer maintain a pedal rate of $>60 \mathrm{rpm}$. Subjects started cycling at $75 \mathrm{~W}$ for $5 \mathrm{~min}$. Thereafter, workload was increased by $50 \mathrm{~W}$ every $2.5 \mathrm{~min}$. When subjects were approaching exhaustion, as indicated by heart rate and subjective scoring, the increment was reduced to $25 \mathrm{~W}$. In practice, this meant that the last one to three load increments were $25 \mathrm{~W}$. Heart rate was registered continuously using a Polar Sport Tester (Kempele, Finland). In each individual, $\mathrm{W}_{\text {max }}$ was calculated from

$$
\mathrm{W}_{\text {max }}=\mathrm{W}_{\text {out }}+(\mathrm{t} / 150) \cdot \partial \mathrm{W}
$$

where $W_{\text {out }}$ is the highest workload completed by the subject, $t$ is the time (in s) performed on the last workload, and $\partial \mathrm{W}$ is the final uncompleted load increment (12).

Glycogen-lowering exercise During the Ex experiments, the subjects came to the laboratory at 1500, after fasting for 2 $\mathrm{h}$, to perform a glycogen-lowering exercise test. It has been shown repeatedly in our laboratory by Kuipers et al. (13) and Wagenmakers et al. (25) that glycogen stores in muscle are significantly decreased in both male and femal e subjects after this exercise test. After a warm-up at $50 \%$ of $W_{\max }$ for $5 \mathrm{~min}$, subjects cycled for $2 \mathrm{~min}$ at $80 \%$ of $\mathrm{W}_{\max }$, followed by $2 \mathrm{~min}$ at $50 \%$ of $\mathrm{W}_{\text {max }}$. This was repeated until subjects were no longer able to perform the high-intensity exercise. The maximal intensity was then lowered to $70 \%$ of $\mathrm{W}_{\max }$. The test was ended after exhaustion, i.e., when subjects could no longer maintain a pedal rate of $>60 \mathrm{rpm}$. Subjects were allowed to consume water during exercise. During the exercise, heart rate was measured continuously with a Polar Sport Tester. Energy expended during exercise was calculated assuming a mechanical efficiency of $20 \%$ (9).

\section{Diets}

Before the experiment, subjects completed a 3-day food intake record to estimate habitual diet composition. Metabolizable energy intake and macronutrient composition of the diet were calculated using the Dutch food composition table (23). In this table, metabolizable energy is calculated by multiplying the amount of protein, fat, and carbohydrate by the Atwater factors $(16.74,37.66$, and $16.74 \mathrm{~kJ} / \mathrm{g}$ for carbohy- drate, fat, and protein, respectively) (14). The amount of protein, fat, and carbohydrate was multiplied by $0.909,0.948$, and 0.953 , respectively, to correct for digestibility of macronutrients. All experimental diets were consumed as breakfast, lunch, dinner, and two or more snacks per day. The composition of experimental diets is given in Table 2. All snacks had the same macronutrient composition as the experimental diet. Food quotient (FQ) was defined as the ratio of $\mathrm{CO}_{2}$ produced $\left(\mathrm{VCO}_{2}\right)$ to $\mathrm{O}_{2}$ consumed $\left(\mathrm{VO}_{2}\right)$ during oxidation of a representative sample of the diet consumed (8).

On days 1 and 2 and the first part of day 3, an RF diet was provided for consumption at home. Subjects were given a fixed amount of food (based on their food intake record) and ad libitum access to snacks. On the evening of day 3 , subjects consumed their dinner and evening snack (either RF or HF) in the respiration chamber. In the RF and HF treatments, energy intake for dinner and evening snack was fixed at 35 and $10 \%$ of estimated daily energy expenditure, respectively [1.7. BMR based on Harris and Benedict equations; for women, $B M R=2.74+0.774 \cdot \mathrm{H}+0.040 \cdot B M-0.020 \cdot A$, and for men, $B M R=0.28+2.093 \cdot \mathrm{H}+0.058 \cdot B M-0.028 \cdot A$, where $B M R$ is basal metabolic rate (in $\mathrm{MJ}$ /day), $\mathrm{H}$ is height (in $\mathrm{m}$ ), $\mathrm{BM}$ is body mass (in kg), and $A$ is age (in yr)] (10). In the RF + Ex and HF + Ex treatments, the evening snack had an energy content equal to energy expended during the exercise test. On day 4, subjects were given an amount of energy equal to 1.55 times sleeping metabolic rate (SMR), as measured during the preceding night. In a previous study (16), it was shown that, with a comparable activity protocol used in the chamber, a physical activity index of 1.58 was reached.

\section{Procedures}

Body composition. Subjects weighed themselves in the respiration chamber on the morning of days 4 and 5 without clothing, after voiding, and before eating and drinking. Measurements were done on a digital balance (Seca Delta model 707) with an accuracy of $0.1 \mathrm{~kg}$.

Whole body density was determined by underwater weighing in the morning with the subjects in a fasted state. Body weight was measured on a digital balance with an accuracy of $0.01 \mathrm{~kg}$ (Sauter type E1200). Lung volume was measured simultaneously by use of the helium-dilution technique using a spirometer (Volugraph 2000, Mijnhardt, The Netherlands). Percent body fat was calculated using the equations of Siri

Table 2. Composition of experimental diets

\begin{tabular}{lcc}
\hline \hline & RF Diet & HF Diet \\
\hline Protein, \% of total energy & 15 & 15 \\
Carbohydrate, \% of total energy & 55 & 25 \\
Fat, \% of total energy & 30 & 60 \\
FQ & 0.88 & 0.80 \\
\hline
\end{tabular}

RF diet, reduced-fat diet; HF diet, high-fat diet; FQ, food quotient. 
(22). Fat-free mass (FFM, in $\mathrm{kg}$ ) was calculated by subtracting fat mass from total body mass.

Indirect calorimetry and physical activity. $\dot{\mathrm{V}}_{2}$ and $\dot{\mathrm{V}}_{\mathrm{CO}_{2}}$ were measured in a wholeroom indirect calorimeter (19). The respiration chamber is a $14-\mathrm{m}^{3}$ room furnished with a bed, chair, television, radio, telephone, intercom, wash bowl, and toilet. The room is ventilated with fresh air at a rate of 70-80 $\mathrm{I} / \mathrm{min}$. The ventilation rate is measured with a dry gasmeter (Schlumberger type G6). The concentrations of $\mathrm{O}_{2}$ and $\mathrm{CO}_{2}$ are measured using a paramagnetic $\mathrm{O}_{2}$ analyzer (Hartmann $\&$ Braun type Magnos $\mathrm{G} 6$ ) and an infrared $\mathrm{CO}_{2}$ analyzer (Hartmann \& Braun type Uras 3G). Ingoing air is analyzed every $15 \mathrm{~min}$ and outgoing air once every $5 \mathrm{~min}$. The gas sample to be measured is selected by a computer that also stores and processes the data. Energy expenditure is calculated from $\mathrm{VO}_{2}$ and $\mathrm{V}_{\mathrm{CO}_{2}}$ according to the method of Weir (26).

In the respiration chamber, subjects followed an activity protocol consisting of fixed times for breakfast, lunch, and dinner, sedentary activities, and bench-stepping exercise. The bench-stepping exercise was performed for $30 \mathrm{~min}$ at intervals of $5 \mathrm{~min}$ of exercise alternated with $5 \mathrm{~min}$ of rest, at a rate of $60 \mathrm{steps} / \mathrm{min}$ and a bench height of $33 \mathrm{~cm}$, and was repeated three times a day. Thus subjects exercised for 45 $\mathrm{min} /$ day at a relative low-to-medium intensity. In the daytime, no sleeping or additional exercise was allowed during the stay in the respiration chamber. All physical activity of the subjects was monitored by means of a radar system based on the Doppler principle.

Urinary nitrogen excretion. During the stay in the respiration chamber, urine was collected in two batches, the first from 2000 to 0800 and the second over the subsequent 24-h interval. Subjects were requested to empty their bladders at 0800. The urine produced was included in the urine sample of the previous batch. Samples were collected in containers with $10 \mathrm{ml} \mathrm{H}_{2} \mathrm{SO}_{4}$ to prevent nitrogen loss through evaporation; volume and nitrogen concentration were measured, the latter with a nitrogen analyzer (Carlo-E rba type CN-O-Rapid).

Twenty-four-hour energy expenditure and substrate oxidation. Subjects stayed in the respiration chamber for $36 \mathrm{~h}$. Data from 2000 on day 3 to 0800 on day 4 are presented for a study of the short-term effects of treatments. For calculation of balances, 24-h energy expenditure (24-h EE) and 24-h respiratory quotient (24-h RQ) were measured from 0800 , on day 4 to 0800 on day 5 . SMR was defined as the lowest mean energy expenditure measured during 3 subsequent hours between 2400 and 0800, with a minimal activity level indicated by the radar system.

Carbohydrate, fat, and protein oxidation were calculated by using $\mathrm{VO}_{2}, \mathrm{VCO}_{2}$, and urinary nitrogen losses with the equations of Brouwer (5)

$$
\text { protein oxidation }(\mathrm{g} / \text { day })=6.25 \cdot \mathrm{N}
$$

fat oxidation $(\mathrm{g} /$ day $)=1.718 \cdot \dot{\mathrm{V}}_{2}-1.718 \cdot \dot{\mathrm{V}} \mathrm{CO}_{2}-0.315 \cdot \mathrm{P}$

carbohydrate oxidation (g/day)

$$
=4.17 \cdot \dot{\mathrm{V}} \mathrm{CO}_{2}-2.965 \cdot \dot{\mathrm{V}}_{2}-0.390 \cdot \mathrm{P}
$$

where $\mathrm{N}$ is the total nitrogen excreted in urine (g/day), $\dot{\mathrm{V}}_{2}$ and $\mathrm{VCO}_{2}$ are measured in liters per day, and $\mathrm{P}$ is protein oxidation (g/day).

Blood analysis. On all four occasions, blood samples were taken on the morning of days 4 and 5 after an overnight fast. F or the collection of blood on day 4, without disruption of the respiration chamber measurement, subjects put an arm through an air lock with a rubber sleeve to fit around the upper arm, positioned under a window for eye contact. On one occasion, blood was sampled on the morning of day 3 . Venous blood $(10 \mathrm{ml})$ was sampled in tubes containing EDTA to prevent clotting and immediately centrifuged at 3,000 rpm $(100 \mathrm{~g})$ for $10 \mathrm{~min}$. Plasma was frozen in liquid nitrogen and stored at $-80^{\circ} \mathrm{C}$ until further analysis. Plasma substrates were determined using the hexokinase method (LaRoche, Basel, Switzerland) for glucose, the Wako NEFA C test kit (Wako Chemicals, Neuss, Germany) for freefatty acids (FFA), the glycerol kinase-lipase method (Boehringer Mannheim) for glycerol and triacylglycerols, and the ultrasensitive human insulin RIA kit (Linco Research, St. Charles, MO).

\section{Statistical Analysis}

All data are presented as means \pm SE. Equality of RQ, FQ, energy intake, energy expenditure, substrate intake, and substrate oxidation was determined by calculating the $95 \%$ confidence intervals for differences. Repeated-measures oneway ANOVA was used to detect differences in any variables between treatments. When significant differences were found, a Scheffé post hoc test was used to determine the exact location of the difference. Differences in any variables between days 4 and 5 were tested by using a paired t-test.

\section{RESULTS}

Time until exhaustion during the exercise test was not significantly different between the RF $+E x$ and HF + Ex treatments: $61 \pm 3$ and $67 \pm 6$ min, respectively. Also, no differences in energy expended during the exercise tests were found: $2.5 \pm 0.2$ and $2.8 \pm 0.3$ MJ for RF + Ex and HF + Ex treatments, respectively.

Body weight, as measured in the respiration chamber, was not significantly different between any of the treatments (Table 3).

SMR measured during the first night was significantly increased in the HF + Ex treatment compared with the RF treatment $(P<0.05)$, most likely because of the effect of exercise on postexercise energy expenditure. However, SMR measured during the second night was not significantly different between any of the treatments (Table 3). Twenty-four-hour energy expenditure (Table 4) and physical activity index (24-h EE/ SMR; Table 3) were not significant different between treatments.

Table 3. Sleeping metabolic rate, physical activity index, and body weight as measured in

\begin{tabular}{|c|c|c|c|c|}
\hline \multirow[b]{2}{*}{ Treatment } & \multicolumn{2}{|c|}{$\mathrm{SMR}, \mathrm{kJ} / \mathrm{min}$} & \multirow[b]{2}{*}{ PAI } & \multirow{2}{*}{$\begin{array}{c}\text { Body Wt, } \\
\mathrm{kg}\end{array}$} \\
\hline & Night 1 & Night 2 & & \\
\hline $\begin{array}{l}\text { RF } \\
\text { RF + EX } \\
H F \\
H F+E X\end{array}$ & $\begin{array}{l}5.09 \pm 0.26 \\
5.25 \pm 0.29 \\
5.11 \pm 0.29 \\
5.33 \pm 0.32 \dagger\end{array}$ & $\begin{array}{l}5.11 \pm 0.29 \\
5.15 \pm 0.28 \\
5.22 \pm 0.27 * \\
5.30 \pm 0.29\end{array}$ & $\begin{array}{l}1.60 \pm 0.05 \\
1.61 \pm 0.04 \\
1.57 \pm 0.03 \\
1.61 \pm 0.04\end{array}$ & $\begin{array}{l}98.5 \pm 6.0 \\
98.7 \pm 5.9 \\
98.2 \pm 5.9 \\
98.2 \pm 5.9\end{array}$ \\
\hline
\end{tabular}
respiration chamber

Values are means \pm SE. SMR, sleeping metabolic rate; PAI, physical activity index, i.e., 24-h energy expenditure/24-h SMR. *P < 0.05 compared with night 1 . $† P<0.05$ compared with RF. 
Table 4. Energy intake, energy expenditure, and energy balance as measured in respiration chamber on four different treatments

\begin{tabular}{lccc}
\hline \hline Treatment & Intake & Expenditure & Balance \\
\hline RF & $12.55 \pm 0.82$ & $11.65 \pm 0.49$ & $0.90 \pm 0.49$ \\
RF + EX & $12.51 \pm 0.82$ & $11.93 \pm 0.62$ & $0.58 \pm 0.43$ \\
HF & $12.53 \pm 0.81$ & $11.76 \pm 0.58$ & $0.77 \pm 0.32$ \\
HF + EX & $12.39 \pm 0.72$ & $12.21 \pm 0.64$ & $0.19 \pm 0.33$ \\
\hline
\end{tabular}

Values are means $\pm \mathrm{SE}$ (in $\mathrm{MJ} /$ day) measured in respiration chamber from 0800 to 0800 .

\section{First 12-h Measurements}

On the evening after the exercise test, subjects were given an amount of energy, as HF or RF diet, to compensate for the energy expended during the exercise bout. Of course, a positive energy balance was therefore measured during the first $12 \mathrm{~h}$ in the chamber. However, this positive energy balance was not significantly different between the RF + Ex and HF + Ex treatments $(2.10 \pm 0.26$ vs. $2.46 \pm 0.35 \mathrm{MJ})$. RQ during the first $12 \mathrm{~h}$ in the respiration chamber was $0.890 \pm 0.009,0.862 \pm 0.014,0.848 \pm 0.006$, and $0.807 \pm 0.01$ for the RF, RF + Ex, HF, and HF + Ex treatments, respectively, and was significantly different between treatments $(P<0.01)$. The RQ in the HF + Ex was significantly lower compared with the RF, RF + $E x$, and $H F$ treatments $(P<0.01)$. RQ values in the RF and HF treatments were also significantly different $(P<0.01)$. In the RF + Ex treatment, a positive carbohydrate balance of $94.5 \pm 16.5 \mathrm{~g}$ and a positive fat balance of $4.5 \pm 6.4 \mathrm{~g}$ were reached, whereas in the $\mathrm{HF}+\mathrm{Ex}$ treatment, those values were $+27.1 \pm 11.7$ and $+38.8 \pm 5.7 \mathrm{~g}$ for carbohydrate and fat, respectively. Thus glycogen was more replete in the RF $+E x$ treatment compared with the HF + Ex treatment, and, as a result, differences in glycogen store were obtained.

\section{Twenty-F our-Hour Measurements}

In all four tests, 24-h energy balance (day 4) was not significantly different from zero (Table 4). Twenty-fourhour RQ was significantly different among all treatments $(P<0.05)$. RQ in the RF and RF + Ex treatments was significantly higher compared with the HF and HF + Ex treatments (Fig. 1). RQ was significantly different from $F Q$ in the RF, HF, and HF + Ex treatments $(P<0.05)$. In the RF + Ex treatment, RQ and FQ were not significantly different (Fig. 1).

Twenty-four-hour protein oxidation was not significantly different between treatments (Table 5). In all treatments, 24-h protein balance was significantly different from zero (Fig. 2, P < 0.05).

Twenty-four-hour carbohydrate oxidation was significantly different between the RF and HF or HF + Ex treatments as well as between the RF $+\mathrm{Ex}$ and $\mathrm{HF}$ or $\mathrm{HF}+$ Ex treatments $(\mathrm{P}<0.01$, Table 5$)$. Carbohydrate balance was significantly different from zero in the RF, $\mathrm{HF}$, and HF + Ex treatments (Fig. 2).
Twenty-four-hour fat oxidation was significantly different between the RF and HF or HF + Ex treatments and between the RF + Ex and HF + Ex treatments $(\mathrm{P}<0.05$, Table 5$)$. Fat balance was significantly different from zero in the RF and HF treatments (Fig. 2). Fat oxidation can be adjusted for energy balance by assuming that, in the case of a positive energy balance, this surplus in energy will be stored as fat, and in case of a negative energy balance, the deficit in energy is accomplished by increasing fat oxidation. When adjusted for energy balance, $24-h$ fat oxidation was $90 \pm 13,106 \pm 15,161 \pm 16$, and $178 \pm 14 \mathrm{~g} /$ day in the RF, RF + Ex, HF, and HF + Ex treatments, respectively.

\section{Blood Variables}

Plasma triacylglycerol concentration increased significantly between days 4 and 5 in the RF + Ex treatment and decreased significantly in the HF treatment. On day 4, plasma triacylglycerol concentration was significantly different between the RF and HF + Ex treatments. On day 5, plasma triacylglycerol concentration was significantly higher in the RF treatment compared with the HF and HF + Ex treatment. In the RF + Ex treatment, plasma triacylglycerol concentration was significantly higher compared with the HF + Ex treatment $(P<0.05$, Table 6). Plasma glucose concentration significantly decreased in the RF treatment between days 4 and 5 and increased in the RF $+E x$ and $H F+E x$ treatments. On day 4, plasma glucose concentration was significantly higher in the RF treatment compared with the HF and HF + Ex treatments. In the RF + Ex treatment, plasma glucose concentration was significantly higher compared with the HF + Ex treatment. On day 5 , no differences in glucose concentrations between treatments were found $(P<0.05)$. There were no significant differences between any days and treatments in plasma FFA and glycerol concentrations.

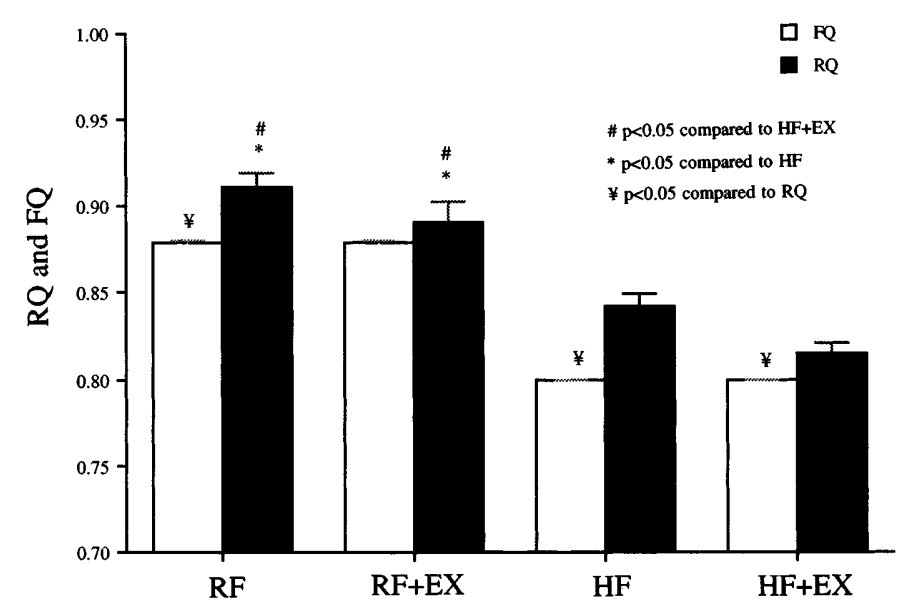

Fig. 1. Twenty-four-hour respiratory $(R Q)$ and food quotients $(F Q)$ as measured in respiration chamber for day 4 (means $\pm S E$ ). HF, high-fat diet; RF, reduced-fat diet; Ex, glycogen-lowering exercise. 
Table 5. Carbohydrate, fat, and protein intakeand oxidation as measured in respiration chamber on four different treatments

\begin{tabular}{|c|c|c|c|c|c|c|}
\hline Treatment & CHO Intake & $\mathrm{CHO}$ Oxidation & Fat Intake & Fat Oxidation & Protein Intake & Protein Oxidation \\
\hline $\mathrm{RF}+\mathrm{EX}$ & $417 \pm 29 * \dagger$ & $400 \pm 21 * \dagger$ & $102 \pm 7 * \dagger$ & $91 \pm 15 \dagger$ & $101 \pm 6$ & $73 \pm 8$ \\
\hline & $207 \pm 14$ & $291 \pm 18$ & $197 \pm 13$ & $140 \pm 11$ & $98 \pm 6$ & $61 \pm 6$ \\
\hline
\end{tabular}

Values are means $\pm \mathrm{SE}$ (in g/day) measured in respiration chamber from 0800 to 0800 . $* \mathrm{P}<0.05$ compared with $\mathrm{HF}$. $\dagger \mathrm{P}<0.05$ compared with HF + EX.

\section{DISCUSSION}

The results of the present study demonstrate that obese subjects are capable of rapidly adjusting fat oxidation to fat intake when glycogen stores are lowered. Therefore, these results are in concordance with the results obtained in lean subjects and do not provide evidence for an impaired capacity to rapidly change fat oxidation in obese subjects. After glycogen-lowering exerdise, fat balance was reached when subjects consumed either an RF or HF diet. These results indicate that obese subjects are capable of maintaining fat balance on an $\mathrm{HF}$ diet when glycogen stores are sufficiently lowered.

One model that can explain the high prevalence of obesity in Western societies is the two-compartment model of Flatt (7). According to this model, fat oxidation can be raised by two mechanisms. First, fat oxidation can be increased when glycogen stores are maintained in a low range. However, in Western societies, with the abundance of food available, people will eat to maintain glycogen stores filled. On an HF diet, this means that people overeat and therefore gain weight (7). Second, the associated expansion of the fat mass will lead to an increase in fat oxidation until a new equilibrium is reached in which average fat intake equals fat oxidation. Ther efore, obesity can be seen as a mechanism to adapt to an HF intake (1). The need for the human body to expand its body fat mass in response to an $\mathrm{HF}$ intake

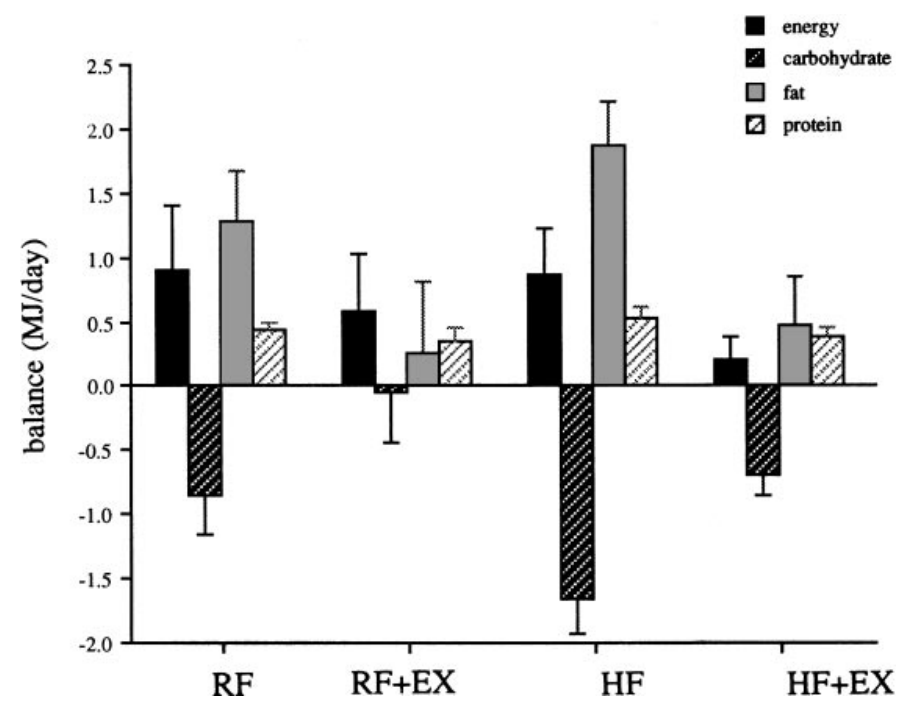

Fig. 2. Twenty-four-hour energy and substrate balances for day 4 as measured in respiration chamber (means $\pm \mathrm{SE}$ ). can be prevented by regular physical activity (18). It is evident that individuals who are regularly physically active are much less prone to become obese compared with sedentary individuals. Exercise reduces glycogen levels, thereby allowing fat oxidation to increase between meals. In this way, fat oxidation can become commensurate with fat intake without expansion of the body fat mass (8). In the present study, we found that fat oxidation was increased sufficiently to match fat intake when glycogen stores were lowered by exhaustive exercise. During the first $12 \mathrm{~h}$ in the respiration chamber, carbohydrate balance was more positive in the RF + Ex compared with HF + Ex treatment (94 \pm 16 vs. $27 \pm 12 \mathrm{~g}$, respectively). It can therefore be assumed that glycogen was more replete in the RF + Ex treatment. The difference in 24-h fat oxidation between the RF + Exand HF + Ex treatments can thus be explained by differences in both glycogen stores and exogenous carbohydrate availability. The higher fat oxidation in the HF + Ex treatment compared with the HF treatment (same exogenous carbohydrate availability) indicates the role of the glycogen in the regulation of fat oxidation. Therefore, these results are in agreement with the model of Flatt and show the impact of physical activity on fat oxidation and indirectly on the prevention of obesity.

It is known that exercise can result in other (hormonal) adaptations that might influence fat oxidation. However, in a study of energy metabolism in the postexercise period, it was found that, $2.5 \mathrm{~h}$ after cessation of exercise, FFA, glycerol, and glucagon concentrations returned to their control values (2). The (hormonal) disturbances induced by exercise therefore are not long lasting. In contrast, the elevation of fat

Table 6. Blood indexes measured on days 4 and 5 in $R F, R F+E X, H F$, and HF + EX treatments

\begin{tabular}{lllllc}
\hline \hline Treatment & Day & $\begin{array}{c}\text { Glucose, } \\
\mathrm{mM}\end{array}$ & $\begin{array}{c}\text { Triacylglycerols, } \\
\mathrm{mM}\end{array}$ & $\begin{array}{c}\text { Fatty Acids, } \\
\mu \mathrm{M}\end{array}$ & $\begin{array}{c}\text { Glycerol, } \\
\mu \mathrm{M}\end{array}$ \\
\hline $\mathrm{RF}$ & 4 & $4.95 \pm 0.14$ & $1.29 \pm 0.19$ & $396 \pm 47$ & $92 \pm 14$ \\
$\mathrm{RF}$ & 5 & $4.88 \pm 0.14^{*}$ & $1.37 \pm 0.19$ & $360 \pm 37$ & $82 \pm 9$ \\
$\mathrm{RF}+\mathrm{EX}$ & 4 & $4.85 \pm 0.13$ & $1.04 \pm 0.16$ & $379 \pm 52$ & $90 \pm 15$ \\
$\mathrm{RF}+\mathrm{EX}$ & 5 & $4.85 \pm 0.14$ & $1.23 \pm 0.16^{*}$ & $359 \pm 46$ & $90 \pm 15$ \\
$\mathrm{HF}$ & 4 & $4.79 \pm 0.13 \dagger$ & $1.18 \pm 0.19$ & $394 \pm 53$ & $90 \pm 15$ \\
$\mathrm{HF}$ & 5 & $4.92 \pm 0.13^{*}$ & $0.99 \pm 0.13^{*} \dagger$ & $366 \pm 43$ & $94 \pm 15$ \\
$\mathrm{HF}+\mathrm{EX}$ & 4 & $4.67 \pm 0.11 \dagger \neq$ & $0.92 \pm 0.12 \dagger$ & $395 \pm 37$ & $119 \pm 17$ \\
$\mathrm{HF}+\mathrm{EX}$ & 5 & $4.83 \pm 0.14^{*}$ & $0.96 \pm 0.11 \dagger \neq$ & $427 \pm 50$ & $107 \pm 12$ \\
\hline
\end{tabular}

Values are means $\pm \mathrm{SE} . * \mathrm{P}<0.05$ compared with day $4 . \dagger \mathrm{P}<0.05$ compared with RF. $¥ \mathrm{P}<0.05$ compared with RF $+\mathrm{EX}$. 
oxidation on the HF + Ex treatment was long lasting, indicated, for example, by RQ during sleep, which was not significantly different between the first and second nights in the respiration chamber (data not shown). We therefore conclude that the increase in fat oxidation cannot be explained by the exerciseitself.

The present study was performed as a follow-up to our previous study in which we showed that lean subjects were capable of rapidly adjusting fat oxidation to fat intake on an HF diet when glycogen stores were lowered by exhaustive exercise. Herewe show the same capacity for obese subjects. However, there are some differences between the two studies. We therefore used the data as described previously (20) to detect any difference between obese and lean subjects by use of unpaired t-tests. RQ during the first $12 \mathrm{~h}$ was not significantly different between obese and lean subjects. Twenty-four-hour RQ was significantly lower in the $\mathrm{RF}+\mathrm{Ex}$ and HF + Ex treatments in lean subjects. However, the results might be influenced by differences in energy balance between the two studies. Energy balance was significantly correlated with fat balance in both obese and lean subjects (Fig. 3; $r^{2}=0.51$, P < 0.001 ). When fat balance was corrected for energy balance, no differences in fat balance between treatments was found in obese and lean subjects. We therefore conclude that obese subjects are as capable as lean subjects of increasing fat oxidation to match fat intake on an HF diet when glycogen stores are lowered. Although the type of exercise used in this study is not likely to be performed by obese people in daily life, the results still indicate the importance of regular exercise in the prevention and/or management of obesity.

Our results seems to be in contrast with studies showing an impaired uptake or oxidation of FFA by the muscle in obese subjects $(3,6)$. However, it is difficult to

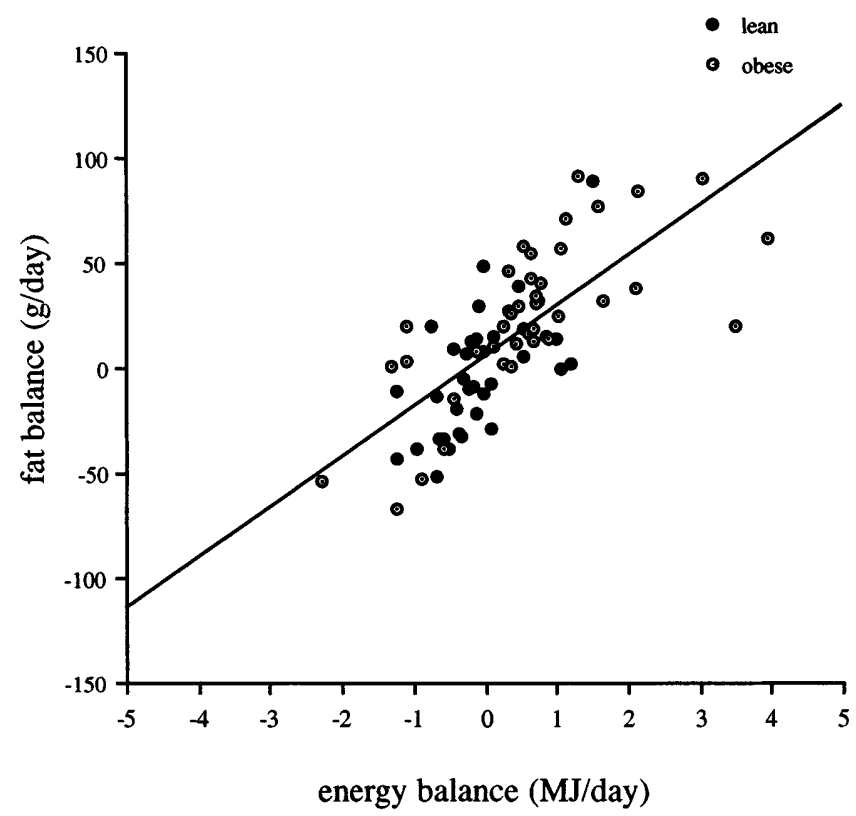

Fig. 3. Relation between 24-h energy balance and 24-h fat balance in obese (present study) and lean subjects (from Ref. 20).

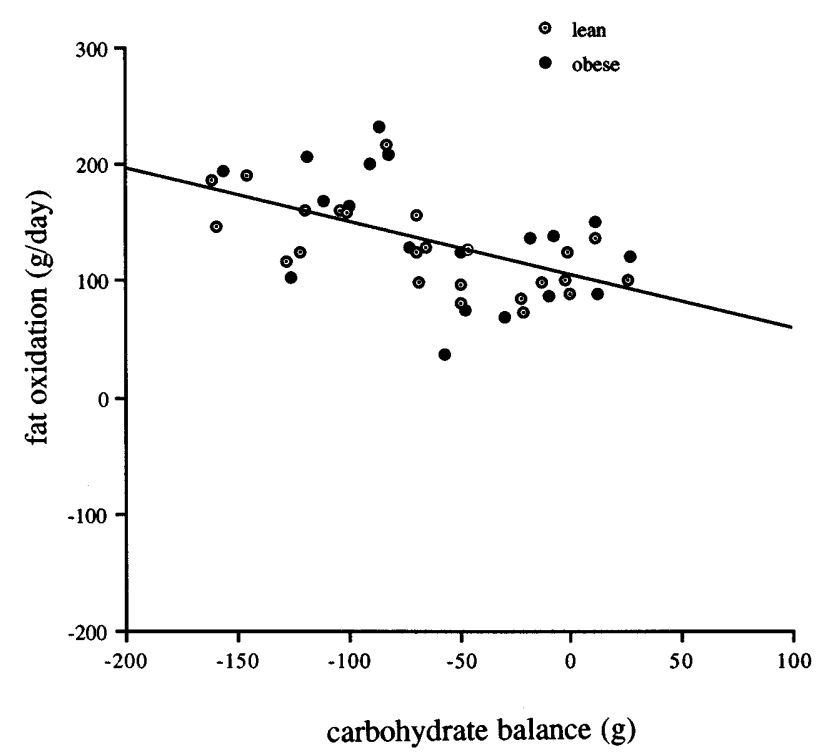

Fig. 4. Relation between carbohydrate balance measured in respiration chamber from 2000 to 0800 and 24-h fat oxidation for obese (present study) and lean subjects (from Ref. 20) in RF + Ex and HF + Ex treatments.

compare those studies with the present study, because we used a 24-h approach. Although we did not find, with prior glycogen-lowering exercise, an impaired capacity to increase fat oxidation on an HF diet when comparing obese with lean subjects, this does not rule out the possibility that there might be an impaired uptake and/or oxidation of FFA on the level of the muscle under certain (stimulated) circumstances. However, further studies must reveal the impact of impaired muscleFFA uptake rates on 24-h fat oxidation.

When we pool the data obtained in obese and lean subjects, we find a negative correlation between carbohydrate balance found during the first $12 \mathrm{~h}$ in the respiration chamber and next 24-h fat oxidation during $\mathrm{RF}+\mathrm{Ex}$ and $\mathrm{HF}+$ Extreatments (Fig. 4; $\mathrm{r}^{2}=0.29, \mathrm{P}=$ $0.005)$. Carbohydrate balance was calculated as measured carbohydrate balance (2000-0800) minus estimated carbohydrate oxidation during exercise. To estimate the latter, it was assumed that $80 \%$ of energy expended during exercise was provided by carbohydrate ( $R Q \sim 0.94)$, which is a reasonable value for this kind of extremely intensive exercise. When carbohydrate oxidation was assumed to provide $90 \%$ of energy expended during exercise, the correlation did not change. These data therefore show the important role of glycogen stores in determining the rate of fat oxidation.

In conclusion, this study shows that obese subjects are capable of rapidly adjusting fat oxidation to fat intake on an HF diet when glycogen stores are lowered by exhaustive exercise. These results may indicate that a lower level of regular physical activity is a predisposing factor for obesity.

Address for reprint requests: P. Schrauwen, Dept. of Human Biology, Maastricht University, PO Box 616, 6200 MD Maastricht, The Netherlands.

Received 5 December 1997; accepted in final form 19 F ebruary 1998. 


\section{REFERENCES}

1. Astrup, A., B. Buemann, P. Western, S. Toubro, A. Raben, and N.J . Christensen. Obesity as an adaptation to a high fat diet: evidence from a cross- sectional study. Am. J . Clin. Nutr. 59: 350-355, 1994.

2. Bielinski, R., Y. Schutz, and E. J équier. Energy metabolism during the postexercise recovery in man. Am. J . Clin. Nutr. 42: 69-82, 1985.

3. Blaak, E. E., M. A. van Baak, G. J . Kemerink, M. T. W. Pakbiers, G. A. K. Heidendal, and W. H. M. Saris. $\beta$-Adrenergic stimulation of energy expenditure and forearm skeletal muscle metabolism in lean and obese men. Am. J. Physiol. 267 (Endocrinol. Metab. 30): E306-E 315, 1994.

4. Bouchard, C. Can obesity be prevented? Nutr. Rev. 54: S125S130, 1996.

5. Brouwer, E. On simple formulae for calculating the heat expenditure and the quantities of carbohydrate and fat oxidized in metabolism of men and animals, from gaseous exchange (oxygen intake and carbonic acid output) and urine N. Acta Physiol. Pharmacol. Neerl. 6: 795- 802, 1957.

6. Colberg, S. R., J .-A. Simoneau, F. L. Thaete, and D. E. Kelley. Skel etal muscle utilization of free fatty acids in women with visceral obesity. J . Clin. Invest. 95: 1846- 1853, 1995.

7. Flatt, J . P. The difference in the storage capacities for carbohydrate and for fat, and its implications in the regulation of body weight. Ann. NY Acad. Sci. 499: 104-123, 1987.

8. Flatt, J . P. I ntegration of the overall response to exercise. Int. J . Obes. 19: S31-S40, 1995.

9. Gaesser, G. A., and G. A. Brooks. Muscular efficiency during steady-state exercise: effects of speed and work rate. J. Appl. Physiol. 38: 1132-1139, 1975.

10. Harris, J . A., and F. G. Benedict. A Biometric Study of Basal Metabolism in Man. Washington, DC: Carnegie Inst., 1919.

11. Klesges, R. C., L. M. Klesges, C. K. Haddock, and L. H. Eck. A longitudinal analysis of the impact of dietary intake and physical activity on weight change in adults. Am. J . Clin. Nutr. 55: 818-822, 1992.

12. Kuipers, H., H. A. Keizer, F. Brouns, and W. H. M. Saris. Carbohydrate feeding and glycogen synthesis during exercise in man. Pflügers Arch. 410: 652-656, 1987.

13. Kuipers, H., W. H. M. Saris, F. Brouns, H. A. Keizer, and C. ten Bosch. Glycogen synthesis during exercise and rest with carbohydrate feeding in males and females. Int. J. Sports Med. 10: S63-S67, 1989.

14. Miles, C. W. The metabolizable energy of diets differing in dietary fat and fiber measured in humans. J . Nutr. 122: 306- 311, 1992.
15. Miller, W. C., A. K. Lindeman, J . Wallace, and M. Niederpruem. Diet composition, energy intake, and exercise in relation to body fat in men and women. Am. J . Clin. Nutr. 52: 426-430, 1990.

16. Pannemans, D. L. E., C. V. C. Bouten, and K. R. Westerterp. 24-h energy expenditure during a standardized activity protocol in young and elderly men. Eur. J . Clin. Nutr. 49: 49-56, 1995.

17. Ravussin, E., and P. A. Tataranni. Dietary fat and human obesity. J . Am. Diet. Assoc. 97: S42-S46, 1997.

18. Saris, W. H. M. Physical activity and body weight regulation. In: Regulation of Body Weight: Biological and Behavorial Mechanisms. New York: Wiley, 1996, p. 135- 147.

19. Schoffelen, P. F. M., K. R. Westerterp, W. H. M. Saris, and F. ten Hoor. A dual-respiration chamber system with automated calibration. J . Appl. Physiol . 83: 2064- 2072, 1997.

20. Schrauwen, P., W. D. van Marken Lichtenbelt, W. H. M. Saris, and K. R. Westerterp. Role of glycogen-lowering exercise in the change of fat oxidation in response to a high-fat diet. Am. J . Physiol. 273 (Endocrinol. Metab. 36): E623-E629, 1997.

21. Schutz, Y., J . P. Flatt, and E. J equier. Failure of dietary fat intake to promote fat oxidation: a factor favoring the development of obesity. Am. J . Clin. Nutr. 50: 307-314, 1989.

22. Siri, W. E. The gross composition of the body. Adv. Biol. Med. Physiol . 4: 239-280, 1956.

23. Stichting-Nederlands-Voedingsstoffenbestand. NEVO Tabel. The Hague, Netherlands: Voorlichtingsbureau voor de Voeding, 1993.

24. Thomas, C. D., J . C. Peters, G. W. Reed, N. N. Abumrad, M. Sun, and J . O. Hill. Nutrient balance and energy expenditure during ad libitum feeding of high-fat and high-carbohydrate diets in humans. Am. J . Clin. Nutr. 55: 934- 942, 1992.

25. Wagenmakers, A.J . M., E.J . Beckers, F. Brouns, H. Kuipers, P. Soeters, van den G. J. Vusse, and W. H. M. Saris. Carbohydrate supplemenation, glycogen depletion, and amino acid metabolism during exercise. Am. J . Physiol. 260 (Endocrinol. Metab. 23): E883-E 890, 1991.

26. Weir, J . B. D. V. New methods for calculating metabolic rate with special reference to protein metabolism. J. Physiol. (Lond.) 109: 1-9, 1949.

27. Zurlo, F., S. Lillioja, D. P. A. Esposito, B. L. Nyomba, I. Raz, M. F. Saad, B. A. Swinburn, W. C. Knowler, C. Bogardus, and E. Ravussin. Low ratio of fat to carbohydrate oxidation as predictor of weight gain: study of 24-h RQ. Am. J . Physiol. 259 (Endocrinol. Metab. 22): E650-E657, 1990. 